\title{
Development of Modified Instant Starch from Taro (Colocasia esculenta) by Gelatinization
}

\author{
Pavankumar R. More ${ }^{1}$, M. I. Talib ${ }^{1}$ and Vishal R. Parate ${ }^{2}$ \\ ${ }^{I}$ (Department of Food Technology, University Institute of Chemical Technology, North Maharashtra University, \\ Jalgaon, India)
}

\begin{abstract}
In present study an attempt to isolate the starch from Taro (Colocasia esculenta) by adopting standard wet milling extraction process. Isolated starch was then pregelatinized to convert into seven samples of instant starch by autoclaving for different duration ranging from $1 \mathrm{hr}$. to $4 \mathrm{hr}$. with 30 minutes increment span. The seven samples of instant starch so prepared were designated as IS-1, IS-1.5, IS-2, IS-2.5, IS-3, IS-3.5 and IS-4 and isolated taro starch was used as control sample (IS O). Starch after gelatinization was dried and packed in polyethylene bag. Isolated starch and instant starch samples were analyzed for; resistant starch content (RS \%), amylose content (\%), water absorption capacity $(g / g)$, swelling power $(g / g)$, solubility $(g / g)$, enzyme digestibility (ED \%) and dispersibility (\%). The functional parameters of Instant starch were compared with control starch (IS-0). Result showed that the RS content of IS-3.0 was reported to be increased with the span of autoclaving and $3 \mathrm{hr}$ was found to be optimum time for making Instant starch with \%RS(30.14). Other parameters of IS3, were \% amylose content (17.21), swelling power $(18.28 \mathrm{~g} / \mathrm{g})$, solubility $(0.099 \mathrm{~g} / \mathrm{g})$, water absorption capacity $(1.72 \mathrm{~g} / \mathrm{g})$, \% enzyme digestibility (59.32) and \% dispersibility (68), while for isolated untreated starch (IS-0) it were amylose content \% (17.83), swelling power (16.02), solubility (0.098), water absorption capacity (1.64), \%enzyme digestibility (56.54) and \% dispersibility (83). Data reveal that functional properties including (water absorption capacity, swelling power, solubility, and enzyme digestibility) were improved in IS3.O. It was reported that amylose content and dispersibility was slightly reduced on autoclaving owing to degradation and retrogradation of starch. Study concludes that instant taro starch can be prepared by pregelatinizing the starch for $3 \mathrm{hr}$ at 15 psi with improved water absorption capacity, swelling power, solubility, enzyme digestibility compared to control starch. Cake prepared from optimum 20\% level of IS-3 starch resulted in cake with better volume and texture.
\end{abstract}

Keywords: Amylose content, instant starch, pregelatinization, resistant starch, retrogradation.

\section{Introduction}

Starch is a carbohydrate consisting of a large number of glucose units joined together by glycosidic bonds. This polysaccharide is produced by all green plants as an energy store. It is the most common carbohydrate in the human diet and is contained in large amounts in such staple foods as potatoes, wheat, maize (corn), rice, and cassava. Depending on the plant, starch contains 20 to $25 \%$ amylose and 75 to $80 \%$ amylopectin [1].

In the early days, starch was considered to be completely digested and absorbed in the small intestine. Later, it was found that a fraction of starch (resistant starch or RS) survived the enzyme digestion in the digestive track [2]. RS is not absorbed in the small intestine, and is passed onto the colon, where it is fermented by the gut microflora. The fermentation of RS in the colon produces short-chain fatty acids and other organic acids $[3,4,5]$, and releases hydrogen through exhalation [6].

RS has demonstrated similar physiological benefits as dietary fibers [7]. and it has been proposed that RS should be included in the definition of dietary fibers [8,9].Consumption of RS has shown to reduce glucose absorption and insulin secretion, which prevents insulin resistance and metabolic syndrome, including obesity, diabetes, and heart disease $[10,11]$. Butyrate, a product of RS fermentation in the colon can prevent the development of cancerous cell in the colon $[12,13]$. Furthermore, the amount of RS that reaches the colon is larger than that of other dietary fibers, thus it is more important as a substrate for colonic fermentation [14]. Examples of RS include raw potato starch, raw high-amylose maize starch, raw green banana starch, and retrograded amylose in bread [15].

RS has been classified into four types according to the nature of the enzyme resistance and the structure of the starch $[16,17]$. RS type 1 (RS1) is physically inaccessible starch, which is protected by a protein matrix or cell wall material, such as that in whole grains, legumes, and pasta. RS type 2 (RS2) is native, uncooked semi-crystalline granular starch that displays the B- and some C-type polymorphs, such as uncooked potato starch, green banana starch, and high-amylose maize starch. RS type 3 (RS3) is retrograded amylose formed in cooked starchy food. RS type 4 (RS4) is chemically modified or cross-linked starch, which is less accessible for 
enzyme hydrolysis. In addition to the four types of RS, resistant dextrins [18, 19] and amylose-lipid complexes $[20,21]$ are also included in RS because they are resistant to enzyme hydrolysis.

Study conducted to determine the nutritional fact of Resistant Starch (RS). RS in food products resists the in vitro enzyme hydrolysis as well as remains undigested in human small intestine. However RS reaches to colon it's being fermented with production of volatile short chain fatty acid. According to literature and present study it may be summarized the development of RS is due to retrogradation of starch and cooling of gelatinized starch. Starch gelatinization is quick process so that developed gelatinized starch can be termed as Instant Starch (IS). Motive of the study is to develop the Instant starch with high RS and improved functional properties Viz. amylose content, water absorption capacity, swelling power, solubility, enzyme digestibility (ED) and dispersibility.

\section{Materials and Methods}

Fresh Taro tubers were purchased from local market of Jalgaon of Varity C. esculenta var. globulifera Engl

\subsection{Extraction of Starch from Tubers}

Taro tubers was collected and cleaned by proper washing. After washing of tubers outer skin was removed by peeling. The tubers ware then sliced and chopped and kept for drying in hot air oven at $55{ }^{\circ} \mathrm{C}$. The dried tuber pieces were then crushed in mixer grinder to form the powder. This powder is further used for isolation of starch. Starch was isolated by standard wet milling process

Taro starch was isolated according to the procedures used by Azhar Ahmed, Farukh Khan (2013) [22]. Taro powder $(50 \mathrm{gm})$ was dispersed in a sodium metabisulphite solution $(150 \mathrm{ml}, 0.45 \% \mathrm{~W} / \mathrm{V})$ for 12 hours at refrigeration temperature. Now the slurry is was milled using a laboratory food blender for 5 min. The blended slurry was mixed with $450 \mathrm{ml} \mathrm{NaCl}$ solution $(0.1 \mathrm{M})$ and $50 \mathrm{ml}$ Toluene. The mixture was agitated for $1 \mathrm{hr}$ and then allowed to stand until the starch granules precipitate at the bottom. The protein in toluene and $\mathrm{NaCl}$ solution layers was siphoned off and discarded, and this was repeated until all of the proteins were removed as indicted by a clear toluene layer after the starch granules settled at the bottom. The starch layer was then washed with water several times and subsequently with absolute ethanol. The wet milled starch was then recovered by filtration through Whatman filter paper, rinsed with ethanol and air dried.

\subsection{Instant starch Preparation (Gelatinization of starch): Autoclaving of Starch:}

Starch gelatinization was performed using the method of Shamai et al. (2003) and Huth et al. (2000) $[23,24]$, with a slight modification. For each treatment, taro starch (180 $\mathrm{g}$ on a dry basis) was weighed in a $1,000 \mathrm{~mL}$ flask before $720 \mathrm{ml}$ distilled water was added (starch: water $=1: 4$, w/v). The flask was then kept on magnetic stirrer for stirring at ambient temperature for $30 \mathrm{~min}$, then covered with aluminum foil and heated by laboratory autoclave for different duration ranging from 1 hour to 4 hour with 30 minutes increment span at $121^{\circ} \mathrm{C}$. After each treatment, the starch gel was cooled at ambient temperature for 2 hours and stored in polythene bags for analysis.

\subsection{Characterization of Isolated starch and instant starch.}

Table 2.1: Methods for the Physicochemical Analysis and Instruments

\begin{tabular}{|l|l|}
\hline Physicochemical analysis & Method and instrument. \\
\hline Moisture (\%) & S. Ranganna1995, Hot air oven \\
\hline Ash (\%) & S. Ranganna1995, Muffle furnace \\
\hline Fat (\%) & S. Ranganna1995, solvent extraction method \\
\hline Protein (\%) & S. Ranganna1995, Protein analyzer (kjaldhal) \\
\hline Crude fiber (\%) & S. Ranganna1995, Crude fiber analyzer \\
\cline { 1 - 2 } Carbohydrates (\%) & S. Ranganna1995[25]., UV-Double Beam Spectrophotometer 2205 \\
\cline { 1 - 2 } RS content (\%) & Onyango et al. (2006) [26], laboratory centrifuge REMI-R4C \\
\cline { 1 - 2 } Amylose content (\%) & Morrison and Laignelet (1983) [27], UV-VIS Spectrophotometer \\
\cline { 1 - 2 } Swelling power (g/g) & Jirarat Tattiyakul et al (2006) [28], laboratory centrifuge REMI-R4C \\
\cline { 1 - 2 } Solubility (g/g) & Medcalf and Gilles (1965) [29], laboratory centrifuge REMI-R4C \\
\hline WAC (g/g) & S. Ranganna1995, Incubator. \\
\cline { 1 - 2 } ED $(\%)$ & AACC 56-61A, 2000b [30].measuring cylinder \\
\cline { 1 - 2 } Dispersibility (\%) &
\end{tabular}

\subsection{Fourier transforms infrared spectroscopy (FTIR)}

Fourier transform infrared spectra were recorded using a Jasco FTIR spectrometer. Starch Particles were collected using the $\mathrm{KBr}$ pellet method. A total of 32 scans were Obtained and the resolution was $4 \mathrm{~cm}-1$. The wavelength region was between 4000 and $400 \mathrm{~cm}-1$. All spectra were baseline corrected and normalized through setting the maximum transmittance to $100 \%$. [31]. 
2.5 Granule microscopy:

Starch granule shapes were observed and photographed using a BX 50 microscope. Granule shape was measured using a microscope fitted with a calibrated eyepiece.

\subsection{Cup cake preparation}

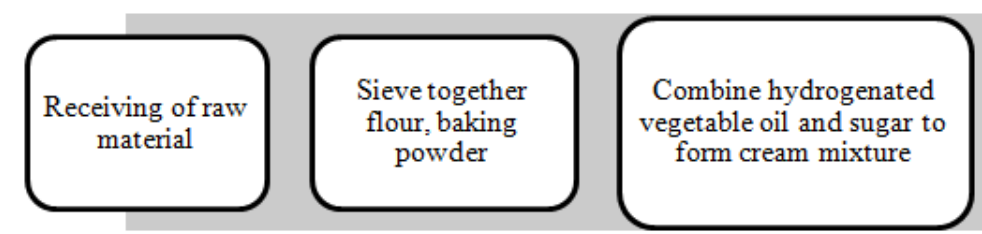

Beat the whole egg to form foam and Mix With cream mixture (Add essence)

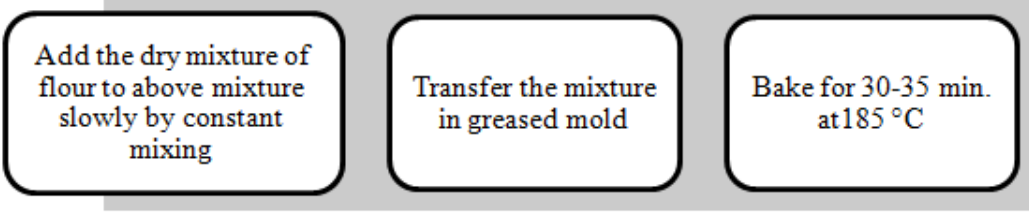

Cool it for $15-20$ min and pack it.

[32].

\subsection{Characterization of cupcake}

\begin{tabular}{|l|l|}
\hline Physicochemical analysis & Method and instrument. \\
\hline Cake Volume & AACC 10-10.03, (2000). \\
\hline Density & AACC $10-10.03,(2000) .[33]$. \\
\hline
\end{tabular}

III. Result And Discussion

Table 3.1: Results of the Compositions of Taro tubers

\begin{tabular}{|l|l|}
\hline Parameter & Gram \% \\
\hline Moisture & $72.5 \pm 0.73$ \\
\hline Ash & $0.94 \pm 0.01$ \\
\hline Fat & $0.26 \pm 0.01$ \\
\hline Protein & $2.45 \pm 0.08$ \\
\hline Crude fiber & $1.21 \pm 0.02$ \\
\hline Carbohydrates & $22.64 \pm 0.73$ \\
\hline
\end{tabular}

Table3.1 showed chemical composition of Taro Tubers of verity C. esculenta var. globulifera Engl Proximate compositions of physical parameters was in between the standard literature values results showed that the parameters were moisture $72.5 \%$, Ash $0.94 \%$, fat $0.26 \%$ And protein $2.45 \%$ but the crude fiber content of taro tuber $w$ as comparatively higher than that of the literature value $(1.21 \%)$.

Figure 3.1 Standard FTIR Spectroscopy of Isolated Taro Starch

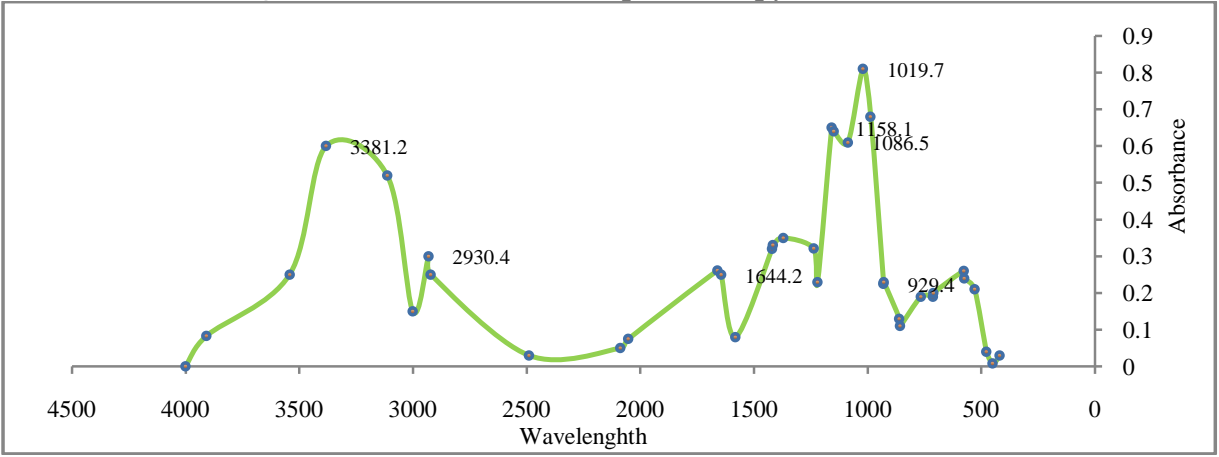


Figure 3.1 showed the fingerprint region of the spectrum, three characteristic peaks appear between 929 and $1158 / \mathrm{cm}$, which are attributed to $\mathrm{C}-\mathrm{O}$ bond stretching. The peaks at 1086 and $1019 / \mathrm{cm}$ are characteristic of $\mathrm{O}-\mathrm{C}$ stretching associated with the anhydroglucose ring. Peak near $850 \mathrm{~cm}-1$ corresponded to the $\mathrm{C}-\mathrm{H}$ deformations another characteristic peak occurs at $1644 / \mathrm{cm}$, which may be related to the presence of tightly bound water in the starch. The peaks appearing at $3381-3800 / \mathrm{cm}$ in the spectrum were due to hydrogen-bonded hydroxyl groups $(\mathrm{O}-\mathrm{H})$, which is attributable to the complex vibrational stretches associated with free, inter-, and intramolecular bound hydroxyl groups, which make up the gross structure of starch. The sharp band at 2930/cm is characteristic of $\mathrm{C}-\mathrm{H}$ stretching associated with the ring methane hydrogen atoms.

Figure3.2: light Microscopic micrograph of taro starch and potato starch granules (isolated) in normal and zoom

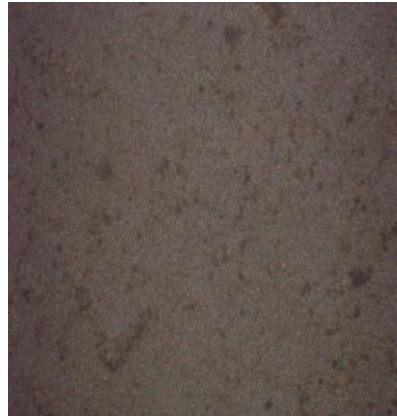

$10 \mathrm{X}$

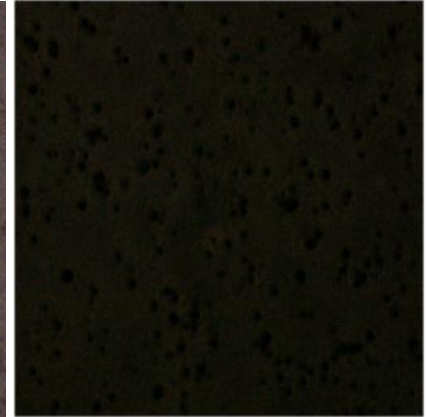

$40 \times($ Zoom)

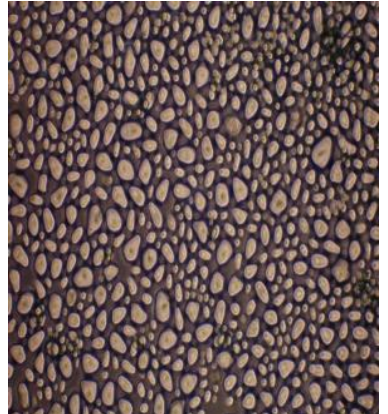

$10 \mathrm{X}$

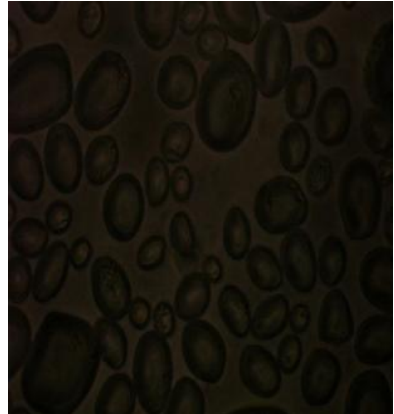

40 X (Zoom)

Figure 3.2 show that the starch granule shapes of potato and taro starches. They were present in different shapes. Light microscopy of starch granules from taro starches as compared with potato starches. The mean dimension of starch granule size measured by microscopy of potato starch was higher than that of taro starch. The particle size distribution of Taro starch was the most homogeneous, while that of potato starch was the most free and separated than Taro Starch. Granule size and particle size distribution are characteristics that markedly influence the functional properties of starch granules [34]. The size range of the taro starch was clearly different from that of potato starch. The granule of taro starch is very small.

\subsection{RS content}

Figure3.3: light microscopic micrograph of Instant Taro starch $121^{\circ} \mathrm{C}$.

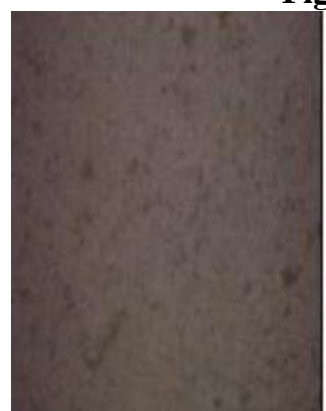

IS-0

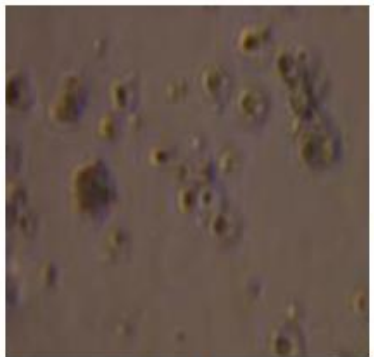

IS- -2.5

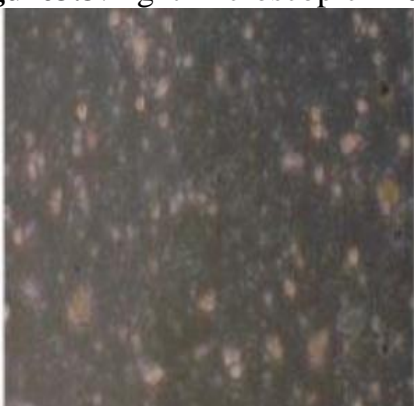

IS-1.0

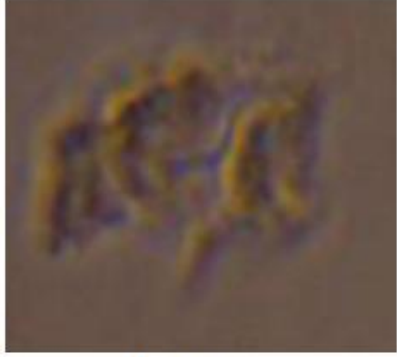

IS-3.0

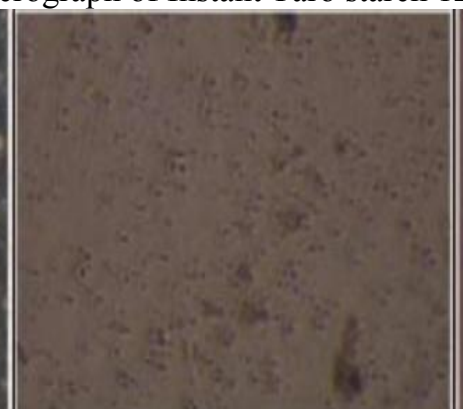

IS-1.5

IS-2.0

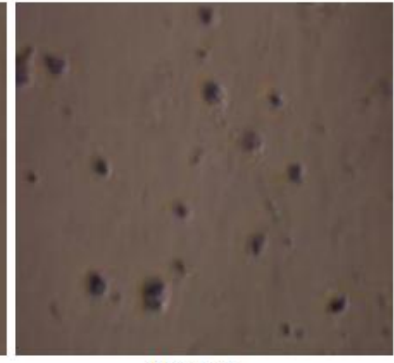

IS-3.5
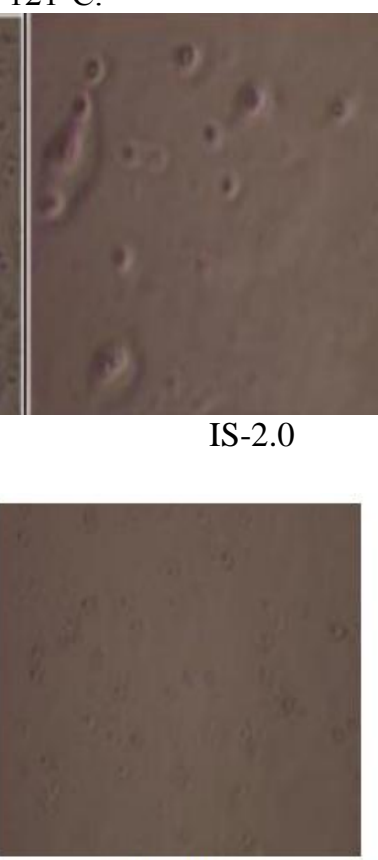

IS -4.0 
Table3.2: Resistant starch content at different autoclaving time

\begin{tabular}{|l|l|}
\hline Autoclaving & Resistant starch (\%) \\
\hline $00 \mathrm{hr}$ (IS-00) & $09.82 \pm 0.18$ \\
\hline $1.0 \mathrm{hr}$ (IS-01) & $23.22 \pm 1.02$ \\
\hline $1.5 \mathrm{hr}$ (IS-1.5) & $26.35 \pm 1.37$ \\
\hline $2.0 \mathrm{hr}$ (IS-2.0) & $28.72 \pm 1.16$ \\
\hline $2.5 \mathrm{hr}$ (IS-2.5) & $29.31 \pm 1.05$ \\
\hline $3.0 \mathrm{hr}$ (IS-3.0) & $30.14 \pm 1.06$ \\
\hline $3.5 \mathrm{hr}$ (IS-3.5) & $29.13 \pm 0.95$ \\
\hline $4.0 \mathrm{hr}$ (IS-4.0) & $28.36 \pm 0.81$ \\
\hline
\end{tabular}

Figure 3.3 shows that the starch granule shapes of native taro starch and after modification $121^{\circ} \mathrm{C} 1 \mathrm{hr}$, $1.5 \mathrm{hr}, 2 \mathrm{hr}, 2.5 \mathrm{hr}, 3 \mathrm{hr}, 3.5 \mathrm{hr}$ and $4 \mathrm{hr}$. Isolated starch granules are oval shape without any hollow area inside and very fine distribution. The hollow area inside the starch granules in IS-1 (1hr) starch was observed but the shapes of the IS-1 (1hr) starch granules are contorted to a folded structure.

Microscopic images showed that gelatinization of starch changed the shape of the starch granules to a folded structure. Folding was highly observed in $2.5 \mathrm{hr}$ and $3 \mathrm{hrs}$ autoclaving. In both $2.5 \mathrm{hr}$ and $3 \mathrm{hr}$ autoclaving the resistant starch content is also comparatively high. In $3.5 \mathrm{hr}$ and $4 \mathrm{hr}$ autoclaving resistant starch content is lesser than $2.5 \mathrm{hr}$ and $3 \mathrm{hr}$ autoclaving.

From this microscopic picture it was well established that starches were modified

Table 3.3: Results of the Physicochemical Analysis of Isolated starch and Instant starch (IS-3)

\begin{tabular}{|l|l|l|}
\hline Parameters & Isolated Starch & Instant starch (IS 3.0) \\
\hline Amylose content $(\%)$ & $17.83 \pm 0.01$ & $17.21 \pm 0.00$ \\
\hline Swelling power $(\mathrm{g} / \mathrm{g})$ & $16.02 \pm 0.01$ & $18.28 \pm 0.01$ \\
\hline Solubility $(\mathrm{g} / \mathrm{g})$ & $0.098 \pm 0.00$ & $0.099 \pm 0.00$ \\
\hline WAC $(\mathrm{g} / \mathrm{g})$ & $1.64 \pm 0.01$ & $1.72 \pm 0.01$ \\
\hline ED $(\%)$ & $59.32 \pm 0.28$ & $56.54 \pm 0.23$ \\
\hline Dispersibility $(\%)$ & $83 \pm 1.22$ & $68 \pm 0.82$ \\
\hline
\end{tabular}

Results of the physicochemical analysis of isolated and IS 3.0 are shown in Table 3.3 as per the result obtained from the analysis. There was $3 \mathrm{hr}$ autoclaving resulted in improvement of resistant starch content $(30.14 \%) \&$ functional properties Viz. Swelling power $(18.28 \mathrm{~g} / \mathrm{g})$ and solubility $(0.099 \mathrm{~g} / \mathrm{g})$ which was higher than that of isolated starch Swelling power $(16.02 \mathrm{~g} / \mathrm{g})$ and solubility $(0.098 \mathrm{~g} / \mathrm{g})$ While dispersibility of IS was quietly reduced it may be due to retrogradation on storage. There was no significant change in the water absorption capacity, enzyme digestibility and amylose content.

Table3.4: Instant starch incorporated cup cake formulations

\begin{tabular}{|l|c|c|c|c|c|c|c|c|}
\hline Ingredients & CAKE0 & CIS-05 & CIS-10 & CIS-15 & CIS-20 & CIS -25 & CIS -30 & CIS -45 \\
\hline Sugar & 100 & 100 & 100 & 100 & 100 & 100 & 100 & 100 \\
\hline Flour & 100 & 95 & 90 & 85 & 80 & 75 & 70 & 55 \\
\hline HMTS (RS) & 00 & 05 & 10 & 15 & 20 & 25 & 30 & 45 \\
\hline Eggs & 2 & 2 & 2 & 2 & 2 & 2 & 2 & 2 \\
\hline Baking powder & 6.3 & 6.3 & 6.3 & 6.3 & 6.3 & 6.3 & 6.3 & 6.3 \\
\hline Fat (Butter) & 40 & 40 & 40 & 40 & 40 & 40 & 40 & 40 \\
\hline Milk & 80 & 80 & 80 & 80 & 80 & 80 & 80 & 80 \\
\hline Condensed Milk & 15 & 15 & 15 & 15 & 15 & 15 & 15 & 15 \\
\hline Salt & 3.0 & 3.0 & 3.0 & 3.0 & 3.0 & 3.0 & 3.0 & 3.0 \\
\hline Vanilla & 2.5 & 2.5 & 2.5 & 2.5 & 2.5 & 2.5 & 2.5 & 2.5 \\
\hline
\end{tabular}

Cake0 (Control): cup cake prepared by wheat flour only.

CIS -5: cup cake prepared by replacing the flour with 5\% Instant starch.

CIS -10: cup cake prepared by replacing the flour with $10 \%$ Instant starch.

CIS -15: cup cake prepared by replacing the flour with $15 \%$ Instant starch.

CIS -20: cup cake prepared by replacing the flour with $20 \%$ Instant starch.

CIS -25: cup cake prepared by replacing the flour with $25 \%$ Instant starch.

CIS -30: cup cake prepared by replacing the flour with $30 \%$ Instant starch.

CIS -45: cup cake prepared by replacing the flour with $45 \%$ Instant starch 
Figure3.4 IS-0 to IS-20

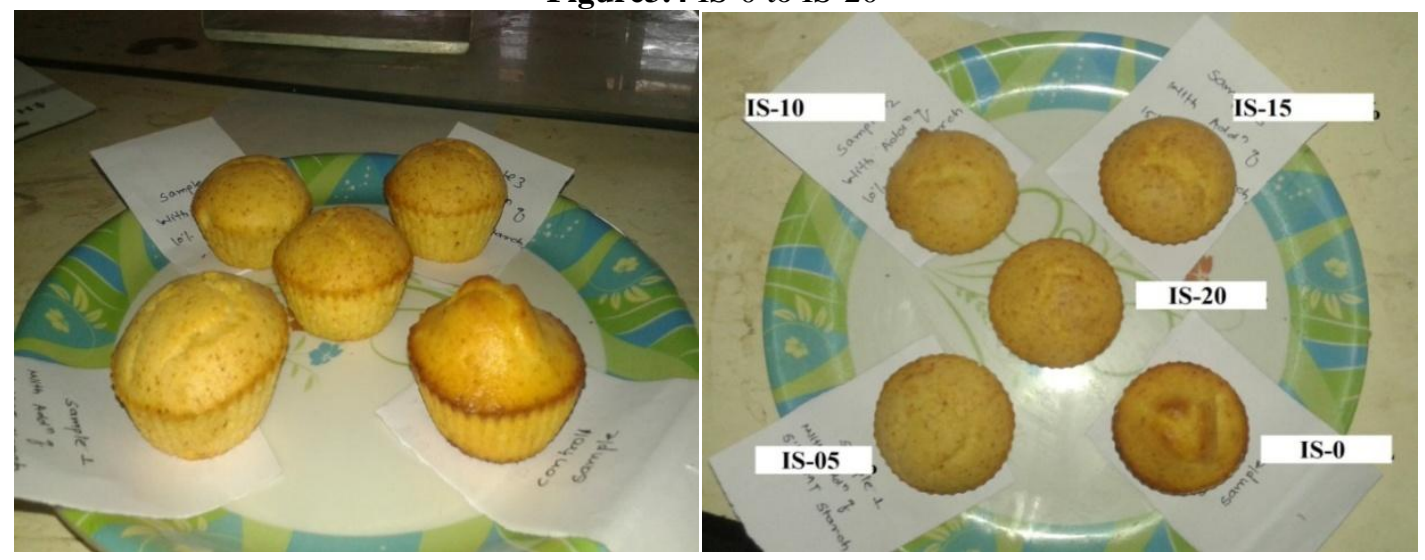

Figure3.5: Cup cakes with IS-0 IS-5, IS-10, IS-15, and IS-20
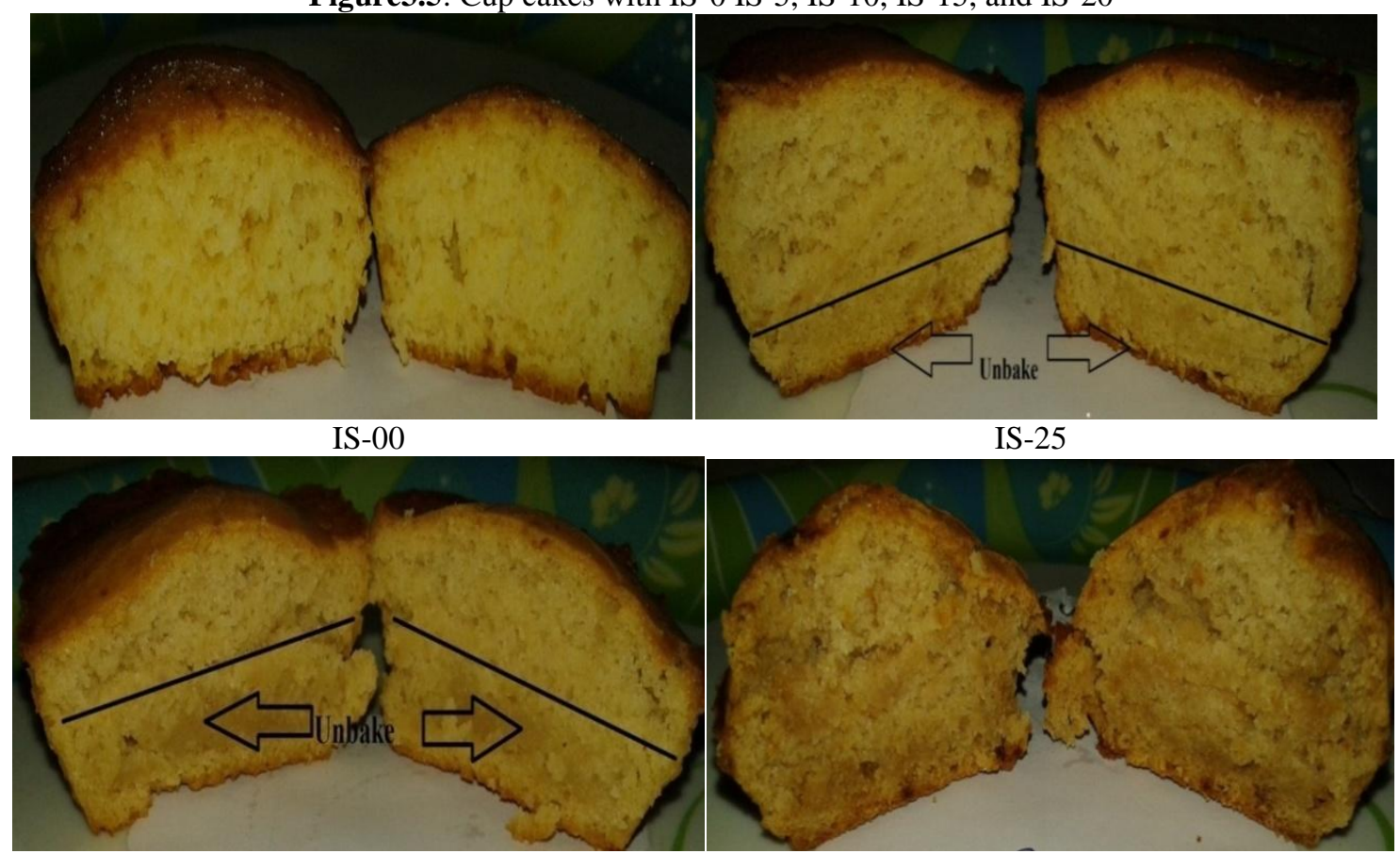

IS-30

IS $-\overline{45}$

Figure3.6: Sensory hedonic chart of cup cake

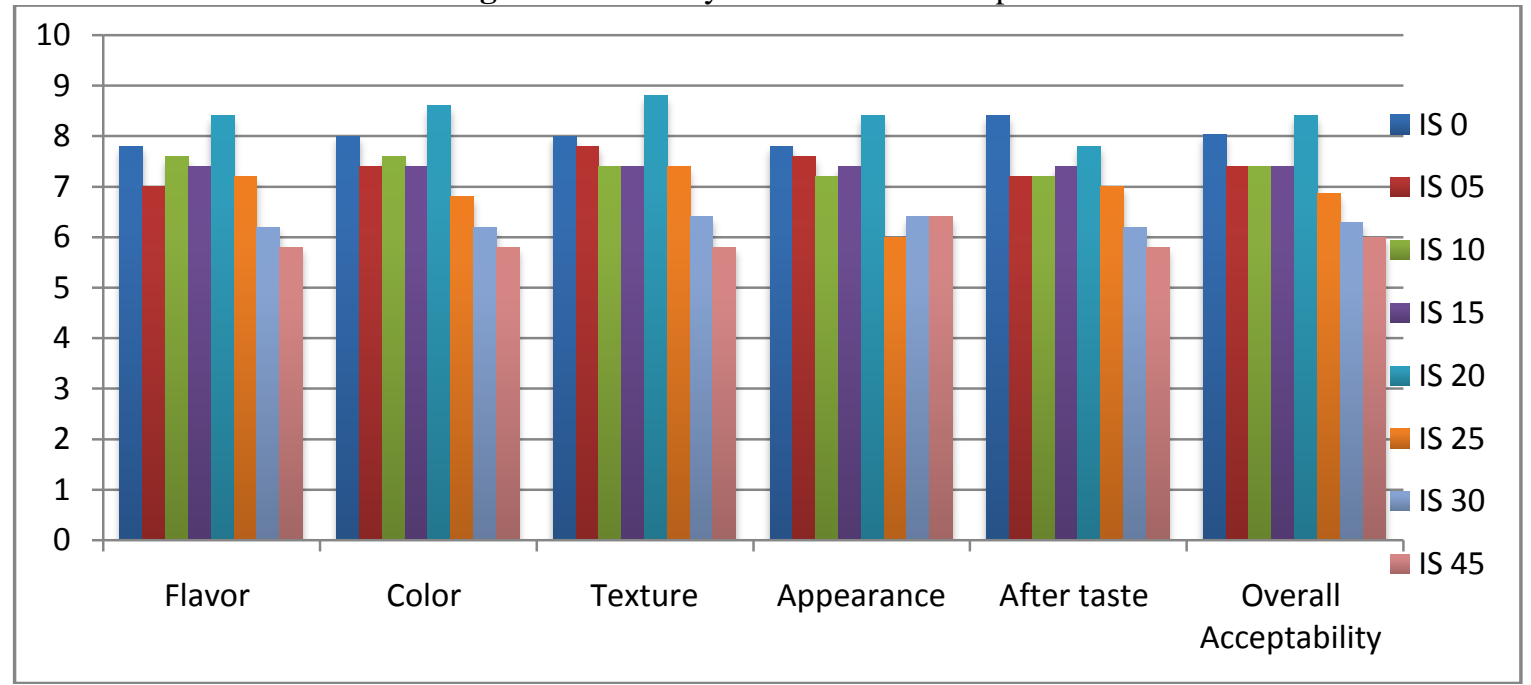


Figure3.6 shows in sample HMTS-5, HMTS-10, HMTS-15 and HMTS-20 successful replacement of HMTS with flour has been done. Properties like texture, sponginess and mouth feel were improved. In sample HMTS-45 there were all the quality parameters are collapse down and such product is unfit for consumption.

In sample HMTS-30 the product is not properly baked. Smoothness and sponginess are not palatable. In HMTS-25 sponginess, volume of cake, texture and other quality parameter are good but slightly product remains unbaked. So it is conceders as unacceptable.

So all the above results shows the best formulation is in CIS-20. It gives grater loaf volume, sponginess, texture, color and other sensory qualities than control sample.

Table 3.5: Physicochemical parameters of CIS-20

\begin{tabular}{|l|l|l|}
\hline Parameter & CAKE0 & CIS-20 \\
\hline Weight $(\mathrm{g})$ & $37.38 \pm 0.73$ & $36.71 \pm 0.56$ \\
\hline Volume $\left(\mathrm{cm}^{3}\right)$ & $111.45 \pm 1.40$ & $116.16 \pm 1.88$ \\
\hline Moisture $(\%)$ & $15.63 \pm 1.31$ & $14.21 \pm 1.06$ \\
\hline Ash $(\%)$ & $1.46 \pm 0.18$ & $1.21 \pm 0.24$ \\
\hline Fat $(\%)$ & $17.86 \pm 0.98$ & $18.23 \pm 1.27$ \\
\hline Protein $(\%)$ & $9.84 \pm 0.75$ & $7.78 \pm 0.98$ \\
\hline
\end{tabular}

Table3.5 showed chemical composition of the produced cake substitutes CIS-20. Moisture content cake of CIS-20 was comparatively lesser than control sample. CIS-20 Cake showed significant differences for total fat and ash content relative to control cake and this may be due to the higher content of total fats and ash in CIS. Protein of CISS20 substituted cake decreased significantly compared with control cake. This may be due to replacement of wheat flour with starch substitution.

Physical attributes (weight, volume, specific volume and density) of wheat flour cake and CIS-20 cake are given in Table 3.5 According to weight data showed no much difference between Cake-0 (37.38) and CIS-20 (36.71). CIS-20 had comparatively high volume $\left(116.16 \mathrm{~cm}^{3}\right)$, than control cake $\left(111.45 \mathrm{~cm}^{3}\right)$. Results had been showed that Instant starch in cake improves the loaf volume, Texture and sponginess of cake rather increases in weight.

\section{Conclusion}

Study concludes that instant starch prepared by $3 \mathrm{hr}$ autoclaving resulted in improvement of resistant starch content $(30.14 \%)$ \& functional properties Viz. Swelling power $(18.28 \mathrm{~g} / \mathrm{g})$ and solubility $(0.099 \mathrm{~g} / \mathrm{g})$ which was higher than that of isolated starch Swelling power $(16.02 \mathrm{~g} / \mathrm{g})$ and solubility $(0.098 \mathrm{~g} / \mathrm{g})$. It was also noticed that the $20 \%$ replacement of Instant starch resulted in improvement in the cup cake quality which might be due to high swelling or gas retention capacity of instant starch.

\section{References}

[1]. Whistler, Roy Lester, and James N. BeMiller, Carbohydrate chemistry for food scientists. Eagan press, 1997.

[2]. Englyst, Hans N., and John H. Cummings, "Digestion of the polysaccharides of some cereal foods in the human small intestine." The American journal of clinical nutrition 42.5 1985, 778-787.

[3]. Holm, J., et al. "A rapid method for the analysis of starch." Starch-Stärke38.7, 1986 224-226.

[4]. Englyst, Hans N., and George T. Macfarlane, "Breakdown of resistant and readily digestible starch by human gut bacteria." Journal of the Science of Food and Agriculture 37.7, 1986, 699-706.

[5]. Wyatt, Gary M., and Nikki Horn, "Fermentation of resistant food starches by human and rat intestinal bacteria." Journal of the Science of Food and Agriculture 44.3, 1988, 281-288.

[6]. Andersen, Melvin E, "A physiologically based toxicokinetic description of the metabolism of inhaled gases and vapors: analysis at steady state." Toxicology and applied pharmacology 60.3, 1981, 509-526.

[7]. Prosky, L., et al, "Determination of insoluble, soluble, and total dietary fiber in foods and food products: interlaboratory study." Journal-Association of Official Analytical Chemists 71.5, 1987, 1017-1023.

[8]. Asp, N-G., J. M. M. Van Amelsvoort, and J. G. A. J. Hautvast, "Nutritional implications of resistant starch." Nutrition research reviews $9.01,1996,1-31$.

[9]. Goodlad, Robert A., and Hans N. Englyst, "Redefining dietary fibre: potentially a recipe for disaster." The Lancet 358.9296, 2001, 1833-1834.

[10]. DeFronzo, Ralph A., and Eleuterio Ferrannini, "Insulin resistance: a multifaceted syndrome responsible for NIDDM, obesity, hypertension, dyslipidemia, and atherosclerotic cardiovascular disease." Diabetes care 14.3, 1991, 173-194.

[11]. Ludwig, David S, "The glycemic index: physiological mechanisms relating to obesity, diabetes, and cardiovascular disease." Jama 287.18, 2002, 2414-2423.

[12]. Jenkins, BMea, L. L. Baxter, and T. R. Miles."Combustion properties of biomass." Fuel processing technology 54.1, 1998, 17-46.

[13]. Ferguson, Lynnette R., et al, "Comparative effects of three resistant starch preparations on transit time and short-chain fatty acid production in rats." Nutrition and cancer 36.2,2000, 230-237.

[14]. Cummings, John H., and Hans N. Englyst, "Fermentation in the human large intestine and the available substrates1'2." fuel 9, 1987, 11 .

[15]. Cummings, J. H., and A. M. Stephen, "Carbohydrate terminology and classification." European Journal of Clinical Nutrition 61, 2007, S5-S18

[16]. Englyst, Hans N., S. M. Kingman, and J. H. Cummings, "Classification and measurement of nutritionally important starch fractions." European journal of clinical nutrition 46, 1992, S33-50. 
[17]. Eerlingen, R. C., and J. A. Delcour, "Formation, analysis, structure and properties of type III enzyme resistant starch." Journal of Cereal Science22.2, 1995, 129-138.

[18]. Brimhall, Bernadine, "Structure of pyrodextrins." Industrial \& Engineering Chemistry 36.1, 1944, 72-75.

[19]. Thompson, A., and M. L. Wolfrom, "The composition of pyrodextrins." Journal of the American Chemical Society 80.24, 1958, 6618-6620.

[20]. Jane, Jay-Lin, and John F. Robyt, "Structure studies of amylose-V complexes and retro-graded amylose by action of alpha amylases, and a new method for preparing amylodextrins." Carbohydrate research 132.1, 1984, 105-118.

[21]. Cui, R., and C. G. Oates, "The effect of amylose-lipid complex formation on enzyme susceptibility of sago starch." Food Chemistry 65.4, 1999, 417-425.

[22]. Azhar Ahmed Et Al, "Extraction Of Starch From Taro (Colocasia Esculenta) And Evaluating It And Further Using Taro Starch As Disintegrating Agent In Tablet Formulation With Over All Evaluation”, Inventi Rapid: Novel Excipients Vol., Issue 2, 2013

[23]. Shamai, Keren, Havazelet Bianco-Peled, and Eyal Shimoni, "Polymorphism of resistant starch type III." Carbohydrate Polymers 54.3, 2003, 363-369.

[24]. Huth, M., et al, "Functional properties of dietary fiber enriched extrudates from barley." Journal of Cereal Science 32.2, 2000, 115128.

[25]. S. Ranganna, Handbook of Analysis and Quality Control for Fruits and Vegetable Product, Second Edition, Tata McGrow Hill Publication. Co. Ltd. New Delhi. 1995.

[26]. Onyango, Calvin, et al, "Influence of incubation temperature and time on resistant starch type III formation from autoclaved and acid-hydrolyzed cassava starch." Carbohydrate polymers 66.4, 2006, 494-499.

[27]. Morrison, William R., and Bernard Laignelet, "An improved colorimetric procedure for determining apparent and total amylose in cereal and other starches." Journal of Cereal Science 1.1,1983, 9-20.

[28]. Tattiyakul, Jirarat, Sukruedee Asavasaksakul, and Pasawadee Pradipasena, "Chemical and physical properties of flour extracted from taro Colocasia esculenta (L.) Schott grown in different regions of Thailand" Science Asia32.3, 2006, $279-284$.

[29]. Medcalf, D. G., and K. A. Gilles, "Determination of starch damage by rate of iodine absorption." Cereal Chem 42, $1965,546-557$.

[30]. AACC (American Association of Cereal Chemists), 10th Edition Adapted from Method 56-61A, 2000b.

[31]. Jiang, Suisui, et al. "Preparation and Characterization of Octenyl Succinic Anhydride Modified Taro Starch Nanoparticles." PloS one 11.2, 2016, $\mathrm{e} 0150043$.

[32]. Zubairuddin, Siddiqui Md, et al, "Development and Quality Evaluation of Ragi Fortified Cake." The Allahabad Farmer Journal 70.2, 2015.

[33]. AACC (American Association of Cereal Chemists), 11th Edition Adapted from Method 10-10.03, 2000.

[34]. Rasper, V, "Investigations on starches from major starch crops grown in Ghana: III.-Particle size and particle size distribution." Journal of the Science of Food and Agriculture 22.11, 1971, 572-580. 